HF in Agile Mfg

$$
\begin{aligned}
& \text { Conf }-951092--1 \\
& \text { SANO95-0348C }
\end{aligned}
$$

\title{
Human Factors in Agile Manufacturing
}

\author{
Chris Forsythe, Sandia National Laboratories, MS 0829, \\ Albuquerque, New Mexico 87185-0829 USA, E-mail \\ jcforsy@sandia.gov
}

As industries position themselves for the competitive markets of today, and the increasingly competitive global markets of the $21 \mathrm{st}$ century, agility, or the ability to rapidly develop and produce new products, represents a common trend (Kovac, 1993, Levary, 1992, Nagel, \& Dove 1992). Agility manifests itself in many different forms, with the agile manufacturing paradigm proposed by the Iacocca Institute offering a generally accepted, long-term vision (Nagel \& Dove, 1992). In its many forms, common elements of agility or agile manufacturing include: changes in business, engineering and production practices, seamless information flow from design through production, integration of computer and information technologies into all facets of the product development and production process, application of communications technologies to enable collaborative work between geographically dispersed product development team members and introduction of flexible automation of production processes. Industry has rarely experienced as dramatic an infusion of new technologies or as extensive a change in culture and work practices. Human factors will not only play a vital role in accomplishing the technical and social objectives of agile manufacturing. but has an opportunity to participate in shaping the evolution of industry paradigms for the 21 st century.

The contributions of human factors to agile manufacturing are as varied as the numerous human components that constitute an industrial enterprise. As a framework for discussing some specific examples relevant to the elements of agility identified above, human factors contributions are categorized as follows: (1.) development of business practices; (2.) design of enabling technologies and (3.) management of the introduction and fielding of new technologies and business practices. The panel session will provide an introduction to these contributions, and an accounting of past and ongoing work. 


\section{DISCLAIMER}

This report was prepared as an account of work sponsored by an agency of the United States Government. Neither the United States Government nor any agency thereof, nor any of their employees, make any warranty, express or implied, or assumes any legal liability or responsibility for the accuracy, completeness, or usefulness of any information, apparatus, product, or process disclosed, or represents that its use would not infringe privately owned rights. Reference herein to any specific commercial product, process, or service by trade name, trademark, manufacturer, or otherwise does not necessarily constitute or imply its endorsement, recommendation, or favoring by the United States Government or any agency thereof. The views and opinions of authors expressed herein do not necessarily state or reflect those of the United States Government or any agency thereof. 


\section{DISCLAIMER}

Portions of this document may be illegible in electronic image products. Images are produced from the best available original document. 


\section{Development of Business Practices}

Implementation of agile manufacturing requires at a minimum, extensive modification of existing business practices, but often, complete overhaul of existing practices (Greiss, 1993). In a market environment where corporate success hinges on rapid turnaround of quality products, each new product development effort can not begin from a blank slate, but instead, corporations must maximize their ability to capture and utilize corporate history and lessons learned (Goldman \& Priess, 1992). Likewise, manufacturing processes fitted to the demands of a given product must be replaced by flexible systems that readily accommodate a range of product parameters (Brost et. al., 1992, Staffend, 1992). Serial progression of designs through the product development cycle is unacceptable, concurrent engineering of designs is desirable, but collaborative design is preferred for fast paced design decisions in an environment that offers little or no tolerance for error (Forsythe \& Ashby, 1994). For the development of agile business practices, there needs to be consideration of human factors affecting decision making within fast paced, dynamic environments (Eisenhardt, 1989). Likewise, knowledge of team dynamics, individual information requirements and information flow, information management and utilization, and monitoring and assessment of the status of complex, dynamic systems is needed (Forsythe \& Ashby, submitted). These are areas that have received considerable attention from human factors within military, space, aviation and traffic domains, but little attention within business contexts, and for which many opportunities exists for the transfer of human factors knowledge and skills across domains.

Of comparable importance to accomplishing the goals of agile manufacturing as product design and manufacture, is the corporate administrative and infrastructure support structure. Of particular concern is support for the communications and information infrastructure. System and software compatibility is essential to the seamless flow of product data through the agile enterprise (Forsythe $\&$ Ashby, submitted). With major vendors on update cycles of six months or less, this compatibility cannot be maintained without the coordination and enpowerment of administrative and support staff. With agile manufacturing, integration and networking of information technologies occurs at all levels of the enterprise. As a consequence, the enterprise must address the support needs of a complex infrastructure and the numerous human points of failure in supporting such an infrastructure (Haney et. al., 1994). When 
information does not flow, due to technical or human causes, agility is lost and for this reason, elimination of human points of failure in infrastructure support is essential (Forsythe \& Ashby, submitted).

\section{Design of Enabling Technologies}

Agile manufacturing is possible primarily as a result of recent and projected technical innovations. Human factors has an important role to play: first in technology development, and secondly, in defining technology systems and their usage (Karwowski, 1994). Use of computer-aided design and manufacturing (CAD and CAM) systems to electronically represent product design is fundamental to agile manufacturing (Bertoline et. al., 1995). Currently, CAD and CAM technologies are advancing at a phenomenal pace, with alternative vendors in a race to keep up with each other. Unfortunately, users express frequent discontent with the usability of these systems. Furthermore, capabilities of CAD and CAM systems are underutilized, partially due to their having not been fully integrated into existing work practices (Forsythe \& Ashby, submitted; Wiebe, 1995). As CAD and CAM systems, as well as related product data managers, are implemented at the enterprise level, preferably, human factors will be incorporated into improved user interface designs, but at the least, human factors and usability should play a large part in benchmarking and similar assessments of alternative commercial products.

\section{Management of the Introduction and Fielding of New Technologies and Business Practices}

The above issues are significant, but the most significant challenges posed by agile manufacturing are sociotechnical (Forsythe \& Ashby, submitted). If users are unwilling or reluctant to accept agile business practices and enabling technologies, agile manufacturing will fail from the inability to overcome the inertia of traditional, often deeply engrained practices. With little exception, businesses that will adopt agile manufacturing over the next five to ten years are currently designing and manufacturing products, with some success. Agile manufacturing poses threats to the comfort of managers and line workers, alike. For management, there is a substantial relinquishment of power by the enpowerment of product development teams and the increased openness of information. For the designer, much control is lost in the collaborative development of designs. At the level of the line worker, there is increased, often 
undesired, responsibility in being brought into the product development decision making process, not to mention the threats posed by computerization and automation of fabrication and assembly tasks. All of these threats occur within an often stressful, fast paced environment in which cognitively demanding decision making tasks replace most mundane, largely undemanding tasks.

\section{Conclusion}

Agile manufacturing will proceed, with or without the contributions of human factors. For the field of human factors, agile manufacturing is, more than anything else, an opportunity. By raising human factors issues, and applying the knowledge and skills gained from other domains, there is an opportunity for human factors to assume an important role, positively influencing the future of agile manufacturing. As of 1995, agile manufacturing is still immature and not yet fully defined. Agile manufacturing poses many questions best answered by human factors. Our willingness, as a profession, to address these questions will determine whether our role is in the definition of a paradigm or in the limited role of afterthe-fact, fixing what is broken.

\section{Acknowledgments}

The author would like to thank Bob Easterling of Sandia National Laboratories for his thoughtful review of this paper. This work was supported by the United States Department of Energy under Contract DE-AC04-95/AL85000.

\section{References}

Bertoline, G.R., Wiebe, E.N., Miller, C. \& Nasman, L. (1995). Engineering Graphics Communications.. Chicago: Irwin.

Brost, R.C., Strip, D.R. \& Eicker, P.J. (1992). The Technology Base for Agile Manufacturing. Presented at NASA Workshop on Space Operations, Houston, TX.

Eisenhardt, K.M. (1989). Making Fast Strategic Decisions in HighVelocity Environments. Academy of Management Journal, 32, (3), 543-576. 
Forsythe, C. \& Ashby, M.R. (1994). Developing Communications Requirements for Agile Product Realization. Sandia National Laboratories, Report No. SAND-94-0481C.

Forsythe, C. \& Ashby, M.R. (submitted). The Role for Human Factors in Agile Manufacturing.

Goldman, S. \& Preiss, K. (1992). 21st Century Manufacturing Enterprise Strategy. Volume 2. Infrastructure. Lehigh University, Bethlehem, PA.

Greiss, H.A. (1993). American Industrial Dominance will Depend upon Agility to Manage Change. Focus, June, 1.

Haney, L.N., Reece, W.J., Wilhelmsen, C.J., \& Romero, H.A. (1994). Modeling Cognitive Aspects of Human Error in Dynamic Tasks. In Advances in Agile Manufacturing: Integrating Technology,

Organization and People, (P.T. Kidd \& W. Karwowski, eds.), ISO Press: Amsterdam, 335-338.

Karwowski, W. (1994). Concurrent Engineering for Enhancing Worker Safety in Robotic Workcells. In Advances in Agile Manufacturing: Integrating Technology, Organization and People, (P.T. Kidd \& W. Karwowski, eds.), ISO Press: Amsterdam, 79-82.

Kidd, P.T. \& Karwowski, W. (1994). Advances in Agile Manufacturing. ISO Press: Amsterdam.

Kovac, F.J. Goodyear (1993). Agility Focuses on Collaboration, Technology and Employee Enpowerment. Focus, June, 2.

Levary, R.R. (1992). Enhancing Competitive Advantage in FastChanging Manufacturing Environments. Industrial Engineering, December, 21-28.

Nagel, R. N. \& Dove, R. (1992). 21st Century Manufacturing Enterprise Strategy. Iacocca Institute, Lehigh University, Bethlehem, PA, 1992.

Staffend, G.S. (1992). Making the Virtual Factory a Reality. AUTOFACT' 92 Conference Proceedings, Dearborn, MI, 15-9-16. 
$\mathrm{HF}$ in Agile Mfg

Wiebe, E.N. (1995). Current CAD/CAM Trends in the Furniture Industry: Initial Findings. Presented at the Association for Engineering Education - Engineering Design Graphics Division Midyear Meeting, Houston, TX. 